\title{
The Optical Properties of Nanoparticle Dispersions Prepared by a High Speed Thin Film Mixer*
}

\author{
Tadahito Takahashi**, Hiroaki Miyamoto***, Takahiro Kono***, \\ Hiroki Gonome ***, Jun Yamada ***, Akihito Shundo ** \\ ** Emulsification and Dispersion Technology Laboratory, Primix Corporation \\ *** Shibaura Institute of Technology
}

\begin{abstract}
Ultrafine particles having diameters in the submicron region have often been used as cosmetic materials because they have excellent optical properties, such as transparency and UV light protection. However, these particles have interfacial energy higher than conventional pigments; thus, they have a tendency to interact with each other to form a secondary agglomeration which may cause deterioration of those functions. To solve these problems, applying high shear force using a high-speed mixer is one of the prospective methods to produce monodispersed uniform dispersion of ultrafine particles. In this study, the relationship between optical properties and highspeed mixing was examined using a high speed thin film mixer. When hydrophilic $\mathrm{TiO}_{2}$ nanoparticles were dispersed in ion-exchanged water, the extinction coefficient decreased in accordance with the peripheral speed of the rotor. Particle size distribution depends on the mixing speed and has good correlation with the increase of distinction coefficient.
\end{abstract}

Key words : high speed thin film mixer, ultrafine particles, nanoparticles, titanium dioxide, particle size distribution, agglomeration, optical property, light scattering, extinction coefficient, albedo

\footnotetext{
* Received, October 11, 2016; Accepted, February 24, 2017

** 1-38, Yumebutai, Awaji 656-2306, Japan

*** 3-7-5, Toyosu, Koto-ku, Tokyo 135-8548, Japan
}

doi.org/10.5107/sccj.51.142

C 2017 The Society of Cosmetic Chemists of Japan 


\title{
高速攪拌機により高分散化した 微粒子組成物の光物性*
}

\author{
高橋唯 仁**, 宮 本紘明***, 河野貴 裕***, \\ 江目宏樹***, 山田 純***, 春藤晃 人** $^{* *}$ \\ **プライミクス株式会社 乳化分散技術研究所 ${ }^{\circledR}$ \\ ***芝浦工業大学工学部機械工学科
}

\begin{abstract}
粒子径がサブミクロン領域にある顔料微粒子は, 透明感, 光沢感, および紫外線遮蔽能などの光学 的特性に優れ, 化粧品素材として汎用されてきた。しかしながら, 微粒子化に伴い表面エネルギーが 高くなるため, 粒子相互の付着性, 凝集性が高くなり, 分散の不均一化に伴う機能低下を生じる場合 がある。これまで, 分散性の向上のため, 粒子の表面処理や形状の制御など, 素材レベルでの改良は 盛んに行われている反面，機械的な処理の効果についてはあまり検討されていない。本研究では，薄 膜旋回型ミキサーを用いて，高速攪拌による微粒子酸化チタンの分散性变化と，分散系に対する入射 光の減衰, 散乱挙動との相関について検討した。その結果, 顔料微粒子が分散した散乱吸収性媒体の 場合, 高速攢拌により高度に均一分散することによって, その光学物性パラメータが变化する現象が 認められたので報告する。
\end{abstract}

\section{1. 緒} 言

近年，粒子径が $1 \mu \mathrm{m}$ 以下の超微粒子が，透明かつ光学 特性に優れた化粧品素材として使用されてきた。しかしな がら，このような超微粒子は通常の顔料粉末に比べ表面活 性が高い状態にあり，物質を吸着しやすい性質がある。こ のため，粒子同士が容易に二次凝集して見かけ上の粒子径 が大きくなり，粒度分布が不均一になることによる機能的 な劣化を生じやすい。たとえば， $\mathrm{TiO}_{2}$ 等における紫外線 遮蔽効果の劣化, あるいは着色顔料の色調や光沢の変化な どである。したがって，化粧品製造時における粒子の集合 状態掞よび分散性の制御は，素材の機能を引き出し，高品 質，高付加価值製品を創出するための重要な因子の一つで ある1

化粧品顔料の分散性を向上させるためには，二つのアプ ローチが考えられる。一つは，粒子の表面処理や形状の制 御など，素材レベルでの改良によるアプローチ22,3)，もう 一つは，高速攪拌機による機械的な分散技術の進化による 製造工程的なアプローチである。このうち，大部分が素材

\footnotetext{
*2016.10.11 受付, 2017.2.24 採用

** $=656-2306$ 淡路市夢舞台 1-38

*** $\bar{\top} 135-8548$ 東京都江東区豊洲 3-7-5
}

レベルでの改良であり，後者のような機械的作用による分 散性の向上と，それに伴う二次的な物性変化については十 分な検証が行われていない。特に, 光学的な性質について は，粒子固有の性質（形状，大きさ，屈折率など）による 違いはよく研究がなされているにもかかわらず，その工程 上の違いによる分散性との相関について，体系的な研究例 は少ない。このような微粒子分散と光学物性の関連性を明 らかにすることは，製品の仕上がりと，紫外光の遮蔽や， 可視光の散乱, 光沢, 色調などとの関係を知る上で非常に 重要な役割を果たすと考える。

そこで本研究では，高速攪拌機を用いた微粒子酸化于夕 ンの分散と光学特性との相関を明らかにすることを目的と し, 薄膜旋回型ミキサー4 (4), 5) 用いて, 親水性酸化チタン を水に分散させたときの光の吸収, 散乱挙動を測定・解析 した。その結果，二次凝集した酸化チタンが高速攪拌によ り効率的に単分散化し, 分散性の向上とともに, その光学 物性パラメー夕に変化がみられることが明らかとなったの で報告する。

\section{2. 実験}

\section{1. 高速攪拌機による酸化チタンの分散}

微粒子酸化チタンとして, 表面がアルギン酸で親水化処 理されたMT-100AQ（テイカ製）を用いた。高速攪拌機と 
して, 薄膜旋回型高速ミキサー, フィルミックス ${ }^{\circledR} \mathrm{FM}-40$ L 型（プライミクス製，以下 FM と略記）を用いた。 Fig.-1 に，FMの断面図と攪汼時の処理液の流動パターンを示 す。FMは，攪拌槽中に容器の内径より若干小さい径の攪 汼羽根を装着し, 高速回転により処理液が壁面に沿って旋 回することによって，粒子にせん断力が与えられる。本研 究では, この攪拌槽中に, 微粒子濃度 $10 \%$ のイオン交換 水分散液 $20 \mathrm{~mL}$ を加え, 攪拌速度（周速）を変化させて 5 分間分散を行った。また, 高速回転時の摩擦熱により容器 内の温度が上昇することを考慮し, 冷却水循環装置（東京 理化機械製，CA-1113）を用いて，攪拌中の容器内温度を $30 \pm 5^{\circ} \mathrm{C}$ に調整した。

\section{2. 酸化チタン分散液の分散性評価}

2.1.の方法で調製した微粒子組成物の分散状態を，動的 光散乱（DLS）による粒度分布測定によって評価した。測 定は，ナノトラックウエーブ粒度分析計（マイクロトラッ ク・ベル製）を用いて行った。また調製したサンプルの分 散安定性を, 試料溶液を 1 力月室温で静置した後, 目視に よって評価した。

\section{3. 酸化チタン分散液の光学特性の評価}

今回, 光学特性については以下の理論から導出される減 衰係数 $\beta$ ，およびアルベド $\omega$ の 2 つのパラメータによって 評価した。液相に微粒子が分散したコロイド溶液は散乱吸 収性媒体と呼ばれ，入射した光の一部は吸収されて熱エネ ルギー等に変換され，一部は散乱されて強度が減衰する。 このとき, 入射光強度を $i$ とおくと, 微小距離 $d s$ だ進 む間の光の減衰挙動は次式のように表すことができる。

$$
\frac{d i}{d s}=-\beta i
$$

このとき， $\beta$ を減衰係数といい，入射光が微粒子媒体中 で吸収，散乱を繰り返すことによって減衰する割合を示 す。この微分方程式を解くと, 式(2)のようになり，媒体 を透過する光は, 指数関数的に減衰する。

$$
i=-i_{0} e^{-\beta s}
$$

さらに光の減衰が吸収と散乱に由来することより，減衰係 数 $\beta$ は, 式(3)のように, 散乱係数 $\sigma_{\mathrm{s}}$ と吸収係数 $\alpha$ の和と して表すことができる。

$$
\beta=\sigma_{\mathrm{s}}+\alpha
$$

ここで，式(4)に示すように，散乱係数 $\sigma_{\mathrm{s}}$ を減衰係数で 割った值をアルベドと定義する。これは，入射光の減衰に 対して，散乱の割合がどれだけかを示す值である。

$$
\omega=\frac{\sigma_{\mathrm{s}}}{\beta}
$$

これらの光物性パラメータの測定は, 波長 $450 \mathrm{~nm}$ から $700 \mathrm{~nm}$ までの可視光領域において, 山田らが開発した測 定装置（芝浦工業大学製）を用いて行った6) -8)。

\section{3. 結果}

\section{1. 高速攪拌による微粒子組成物の調製と分散安定性}

高速攪拌時の回転数（周速）を変化させた時の粒度分布 の変化を Fig.-2に示す。使用した酸化チタンは, 親水化 処理されているため，見かけ上分散性には優れているが， 高速攪拌処理前の状態において，一次粒子が凝集した状態 で存在していると推測される。すなわち, イオン交換水に 単純に分散しただけでは，DLSによる測定において， $1 \mu \mathrm{m}$ 以上の領域と $150 \mathrm{~nm}$ 付近に複数の極大をもつ分布を 示し，微視的には不均一であった。それに対し，FMで高 速攪拌することにより, 周速の増加とともに $1 \mu \mathrm{m}$ 以上の 二次凝集体が覺拌速度の増大とともに消失して, $150 \mathrm{~nm}$ 付近のシングルピークにほほ収束した。

FM での高速攪拌処理は, 安定性の向上に寄与すること が分かった。その様子を Fig. -3 に示す。室温で 1 力月静 置して分散安定性を比較したところ，低速で調製した試料 は, 粒子の再凝集による明らかな沈殿が現れたのに対し, 攪拌速度が速いほど粒子の沈降が遅く, 特に周速 $40 \mathrm{~m} / \mathrm{s}$ で分散したものでは，1 カ月後もほほ同様の分散状態が保 たれ，沈殿物はみられなかった。これらの結果は，永井ら の報告による FM で調製した $\mathrm{O} / \mathrm{W}$ エマルションの分散 安定性と一致するものであり, 高速で攪拌するほど凝集速 度が遅く，安定な分散系となることが示された5)。

\section{2. 高速攪拌した微粒子組成物の光学物性}

周速と減衰係数 $\beta$ との関係を Fig. -4 に示す。周速が増 加するにつれて，照射された光は減衰するようになった。 これは粒度分布（Fig.-2）が示すとおり，凝集した粒子 $(>1 \mu \mathrm{m})$ が擋汼され小さな粒子 $(<400 \mathrm{~nm})$ となり，粒 子単体の減衰効率が上昇したためである ${ }^{6}$ 。また，高速攪 拌時には, 生成する微細気泡の影響が考えられるので, 真 空ポンプ (ULVAC, G-101S) で約 1 分間脱気後の測定值と の比較を行った (Fig. -5$)$ 。数值的には若干の減少が認め られたものの, 周速との関係は同様のパターンを示した。 これらの結果は, 分散性の違いが光の散乱に影響を与える ことを示唆するものである。

一方，散乱の指標であるアルベド $\omega$ を測定した結果， 攪拌速度の変化とは無関係に 1 に限りなく近い一定值を示 した (data not shown)。可視光域において, 酸化チタンに よる光の減衰は，理論計算 ${ }^{6}$ が示すとおり，ほぼ $100 \%$ が 散乱による減衰であることが数值的に示された。 

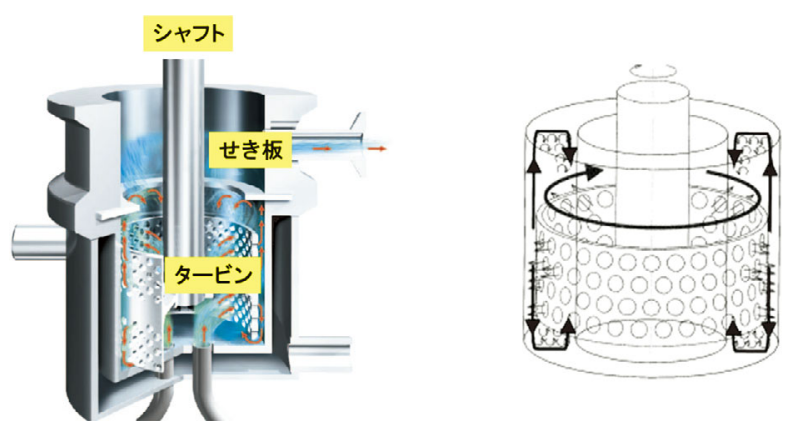

Fig. -1 Section structure of high speed thin film mixer with an image of the liquid flow.

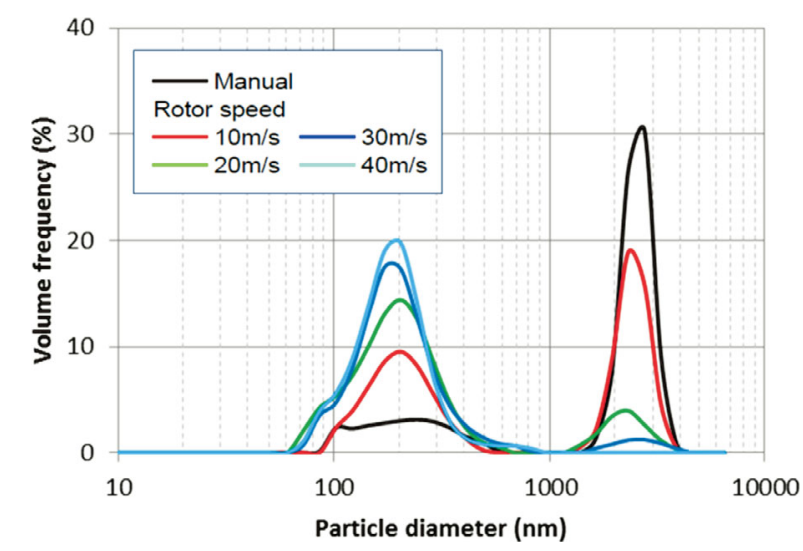

Fig.-2 Particle size distributions of freshly prepared fine particle dispersions in relation to mixing speed.

\section{4. 考}

察

薄膜旋回型ミキサーFM を用いて周速 $30 \mathrm{~m} / \mathrm{s}$ 以上の高 速攪拌処理を行うことにより, 粒径 $1 \mu \mathrm{m}$ 以上の凝集体は ほぼ消失し，150 nm 付近に極大を持つ単分散となった。 微粒子の分散の進行は，外力によるせん断と粒子表面のぬ れの効果に依存する。今回使用した微粒子酸化チタンは,

表面が水溶性高分子で処理されており，ぬれ性に優れ容易 に水分散できるタイプである。しかしながら，粒度分布の 結果を見ると，見かけ上は均一でも，微視的には複数の ピークを示し不均一であることがわかる。今回，高速攪拌 処理を行い，せん断をかけることによって，集合体や凝集 体が解砕され，単分散に近い状態にすることができた。顔 料微粒子の二次凝集のうち, 分子間力や物理吸着のような 比較的弱い結合によるものは，高速攪拌機によるせん断力 で容易に分散させることができると考える。したがって， 二次凝集した微粒子の再分散ばかりでなく，他の方法で作 製した分散液の追加処理として，FM 処理工程を加えるこ とも，分散性の向上には有効な方法である。

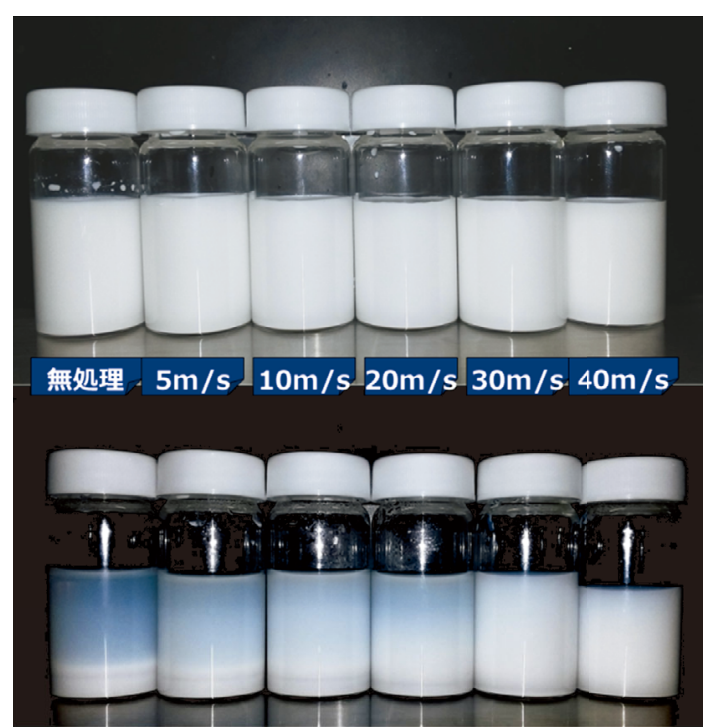

Fig.-3 Stability of $\mathrm{TiO}_{2}$ dispersions a month after preparation.

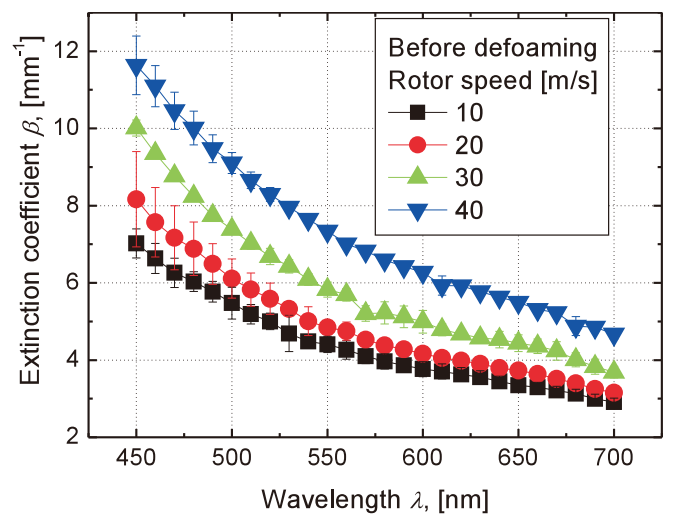

Fig.-4 Correlation between rotor speed and extinction coefficient without defoaming.

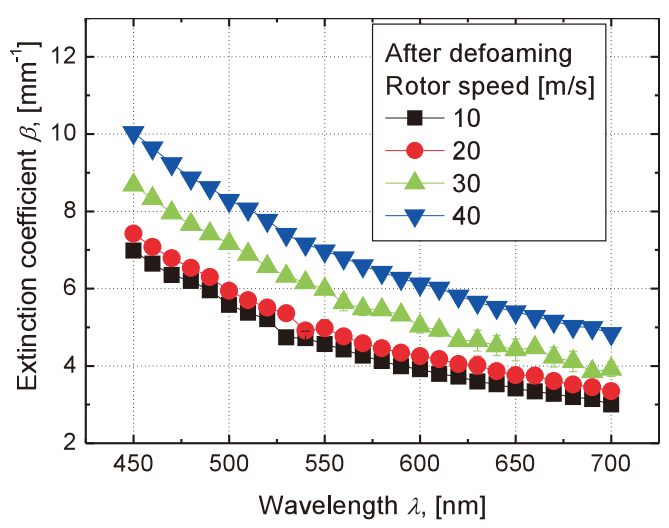

Fig.-5 Correlation between rotor speed and extinction coefficient after defoaming.

また，薄膜旋回型ミキサーのもう一つの利点は，一次粒 子にダメージを与えない温和な分散法であるところにあ る。すなわち，FMで高せん断をかけた場合でも粒子表面 
のダメージがほとんどないことが確認されている4),5)。Fig.-4 に示すように，いったん解砕された粒子の再凝集が抑制さ れ，分散状態が安定に維持されたのは，処理表面のダメー ジが少なく，表面の親水性がそのまま維持されていること が一つの理由と考えられる。同様な湿式での微粒子の解砕 には，湿式メディアミルや高圧ジェットミルが使用される ことが多い。これらの方法は，メディアの混入や，大きな 衝撃力による粒子表面の直接的なダメージに由来する性質 の変化を生じやすい。それに比較して，薄膜旋回法による 高速攪拌は, 凝集体の解砕と同時に, 精密に表面設計され た処理粉体を扱う場合にも適した方法といえる。

光物性の測定結果より，微粒子媒体に入射した光が散乱 を繰り返しながら減衰していく過程が，分散性とよい相関 にあることが示された。言い換えれば，光の吸収特性に影 響を与えずに媒体の光散乱特性を制御できることを示して いる。今回検討した波長領域は，光沢，明るさ，透明感な どの物性に関与する領域であり，高速攪拌の前後で減衰係 数が大きくなることは，製品の仕上がり状態の違いで，見 た目に変化が生じる可能性を示している。

山田らは，そのような官能的な評価を数值的に解析する

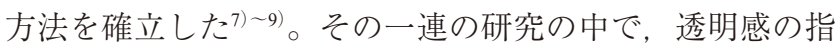
標として，減衰係数が関与することを示した報告があ る ${ }^{10)}$ 。それによると, 光学厚さが小さい領域では幾何学厚 さが小さいほど透明感が強い傾向があり, 光学厚さは幾何 学厚さと減衰係数との積で表されるので, 媒質の光学厚さ が等しく, 幾何学厚さが小さいサンプルは, 必然的に大き な減衰係数をもつことになる。減衰係数と官能的な諸性質 の直接的な関連性に言及した研究例は少ないが，少なくと も分散性の違いにより減衰係数が変化した事実は，高速攪 拌によって視覚に関連する物性を制御できる可能性を示唆 するものである。

酸化チタンによる紫外線遮蔽効果において, 遮蔽能が最 大になる至適粒子径の存在が報告されている ${ }^{11), 12) 。 お そ ~}$
らく可視光領域での光物性においても，紫外光領域と同様 な至適粒子径が存在するものと考えられる。その場合，実 際に効いてくるのは組成物としての平均粒径であり，素材 レベルで精密に粒子径を設計することと同様に，高速攪拌 による凝集体，集合体の制御により，粒度分布を至適粒子 径に均一化することが非常に重要であると考える。

\section{5. 結}

論

高速攪汼が光物性に与える影響を検討した結果，散乱が 支配的な可視光領域において，高速攪拌による単分散化に より，入射光が減衰しやすいことが示された。この結果 は，高速攪拌による分散性の制御によって，光の遮断，質 感，光沢などの視覚的な付加価值を付与することができる 可能性を示すものである。

\section{引用文献}

1）林一之, 粉砕, 51, 37-43 (2008)

2）那須昭夫，色材協会誌，78, 283-287 (2005)

3）神谷秀博, 飯島志行, 粉砕, 55, 12-18 (2012)

4）春藤晃人，粧技誌， 42, 30-35（2008）

5）永井康子, 麻 彪, 石津敬司郎, 粧技誌, 39, 26-30 (2005)

6) M. Banesi, S. Maruyama, H. Nakai, A. Komiya, J. Quant. Spectrosc. Radiat. Transf., 110, 192-204 (2009)

7）山田 純, 川村 歩, 三浦由将, 高田定樹, 小川克 基，日本機械学会論文集，71，1436-1444（2005）

8）山田 純, 有田悠一, 安 炳弘, 三浦由将, 高田定 樹，日本機械学会論文集，74, 2034-2039（2008）

9) K. Naito, J. Yamada, T. Ogawa, S. Takata, Netsu Bussei, 24, 101-108 (2010)

10）山田 純, 神 佳弘, 岡本 諭, 日本機械学会論文 集, 81,830 (2015)

11）次田 章, 粧技誌, 27, 119-129（1993）

12）坂本正志，奥田晴夫，二又秀雄，坂井章人，飯田正 紀，色材協会誌，68，203-210（1995） 